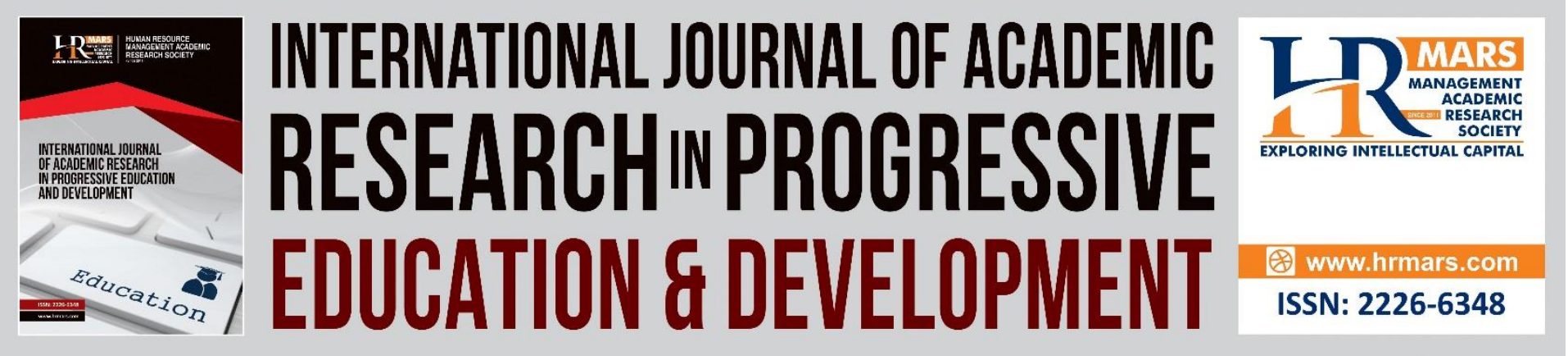

\title{
Women's Awareness of the Cyberbullying Risk in Digital Media During the Enforcement of the Movement Control Order (MCO)
}

Mohammad Fahmi Abdul Hamid, Khairul Azhar Meerangani, Mohd Farhan Md Ariffin, Izzah Nur Aida Zur Raffar, Siti Nurul Izza Hashim, Abdul Muiez Mohammad Ruslee

To Link this Article: http://dx.doi.org/10.6007/IJARPED/v11-i1/12049 DOI:10.6007/IJARPED/v11-i1/12049

Received: 20 November 2021, Revised: 23 December 2021, Accepted: 09 January 2022

Published Online: 24 January 2022

In-Text Citation: (Hamid et al., 2022)

To Cite this Article: Hamid, M. F. A., Meerangani, K. A., Ariffin, M. F. M., Raffar, I. N. A. Zur, Hashim, S. N. I., \& Ruslee, A. M. M. (2022). Women's Awareness of the Cyberbullying Risk in Digital Media During the Enforcement of the Movement Control Order (MCO). International Journal of Academic Research in Progressive Education and Development, 11(1), 273-282.

Copyright: (C) 2022 The Author(s)

Published by Human Resource Management Academic Research Society (www.hrmars.com) This article is published under the Creative Commons Attribution (CC BY 4.0) license. Anyone may reproduce, distribute, translate and create derivative works of this article (for both commercial and non-commercial purposes), subject to full attribution to the original publication and authors. The full terms of this license may be seen at: http://creativecommons.org/licences/by/4.0/legalcode

Vol. 11(1) 2022, Pg. 273 - 282

http://hrmars.com/index.php/pages/detail/IJARPED

JOURNAL HOMEPAGE

Full Terms \& Conditions of access and use can be found at http://hrmars.com/index.php/pages/detail/publication-ethics 


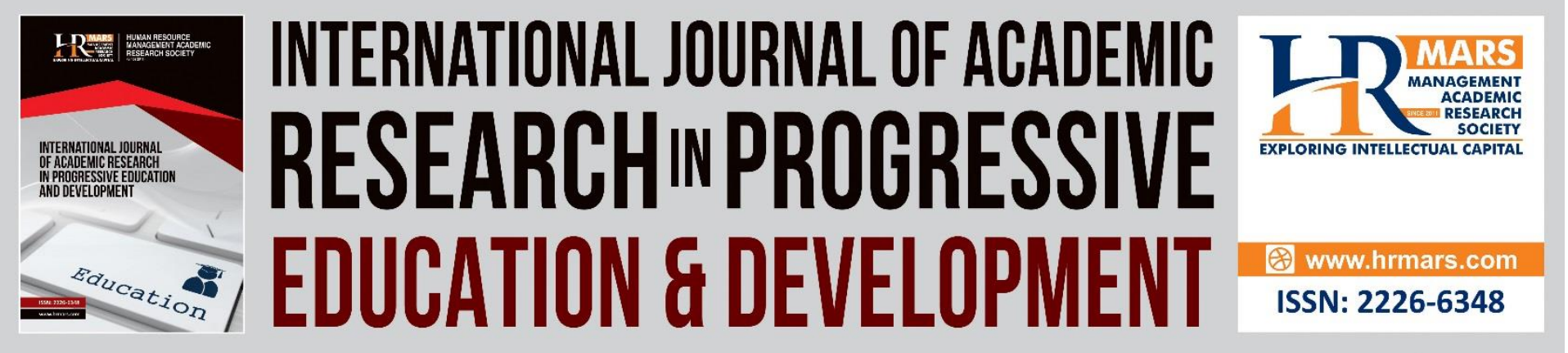

\title{
Women's Awareness of the Cyberbullying Risk in Digital Media During the Enforcement of the Movement Control Order (MCO)
}

\author{
Mohammad Fahmi Abdul Hamid, Khairul Azhar Meerangani
} Akademi Pengajian Islam Kontemporari, Universiti Teknologi MARA Cawangan Melaka

Mohd Farhan Md Ariffin

Centre for Quran and Sunnah Studies, Faculty of Islamic Studies, Universiti Kebangsaan Malaysia

\section{Izzah Nur Aida Zur Raffar, Siti Nurul Izza Hashim}

Akademi Pengajian Islam Kontemporari, Universiti Teknologi MARA Cawangan Melaka

\author{
Abdul Muiez Mohammad Ruslee \\ Sekolah Menengah Kebangsaan Sungai Besar, Selangor
}

\begin{abstract}
Malaysia is the 9th country to record the most active social media usage worldwide, which is attributed to almost $80 \%$ of its total population. The enforcement of the Movement Control Order (MCO) following the threat of COVID-19 pandemic since 18 March 2020 has introduced Malaysians to the new norms, including the use of digital media and online applications for various purposes and needs. The Malaysian Communications and Multimedia Commission (MCMC) reported a sharp increase in demand for broadband and internet traffic flow since the implementation of MCO due to business activities, learning, conferences, meetings and so on, which are conducted from home. In the meantime, a total of 3,075 cyber security incidents were reported only in the period of between March 18 and July 31 in 2020 with $109.4 \%$ increase over the same period in the previous year. Based on statistics, almost $60 \%$ of the cyberbullying victims are reported to be women. Thus, this study aims to analyse the exposure of women to the risk of cyberbullying in digital media during the enforcement of MCO. The study was quantitatively conducted using a survey design in which a set of online questionnaires (Google Form) was distributed to 296 respondents in Melaka, all of them are women. It is summarised from the study findings that the types of cyber harassment experienced by respondents include taunting and humiliating remarks in digital media (40.2\%), digital accounts were hacked (28.3\%), sexual harassment (32.4\%), and physical harassment (16.5\%). Therefore, awareness of the rights and responsibilities of digital media users shall be enhanced to establish a harmonious and safe digital ecosystem in society.
\end{abstract}


DEVELOPMENT

Vol. 11, No. 1, 2022, E-ISSN: 2226-6348 @ 2022 HRMARS

Keywords: Internet, Women, Cyberbullying, Digital Media, Cyber Security

\section{Introduction}

The Industrial Revolution 4.0 has contributed to the rapid development in information and communication technology. To ensure that Malaysia does not lag behind in this development, the government has designed a Comprehensive Roadmap for the Industrial Revolution 4.0 (IR 4.0) and National Digital to ensure that the digital infrastructure carried through in the country can benefit all citizens, thereby driving the nation economic growth. This direction shall focus on six key components namely development of digital talent, new technologies, the economy of all, society, and government-related affairs. Furthermore, the government under the 12th Malaysia Plan (2021-2025) is committed in the efforts to improve the country's digital communications via implementation of the digital infrastructure plan, known as the National Digital Network (JENDELA). This platform is essential in providing comprehensive and high-quality broadband service coverage, thus preparing the country for a steady transition to $5 \mathrm{G}$ technology. The government has also injected extra investment worth RM400 million through the Prihatin Rakyat Economic Stimulus Package (PRIHATIN), to enable the telecommunications industry to reinforce the performance of their respective networks. Thus, all entities including the state governments, local authorities, ministries, and relevant agencies have been mobilised to support the government's aspiration to make communication services a basic facility to drive the country towards a digital economy.

In the meantime, the coronavirus disease 2019 (COVID-19) epidemic that was first detected in Wuhan, China late 2019 spread like a streak into a pandemic, changing the domestic and international landscape nowadays. As of September 2020, almost 30 million people worldwide have been confirmed positive for the COVID-19 virus with the death toll reached 1 million people. Malaysia is among the countries that are affected by the spread of this epidemic, although the initial cases took place a bit slow, which was only 22 in January 2020. However, the emergence of the 'Sri Petaling Cluster' which was detected on March 11, 2020 following the gathering of tabligh group at Sri Petaling Mosque, saw a sharp increase in the number of individuals who tested positive for COVID-19, reaching three figures daily. Such incident has caused the government to enforce the Movement Control Order (MCO) in stages, starting from MCO Phase 1 (18-31 March 2020), MCO Phase 2 (01-14 April 2020), MCO Phase 3 (15-28 April 2020), and MCO Phase 4 (April 29-May 12, 2020). During this period, the government itself has enforced several Standard Operating Procedures (SOP), including restriction of movement and activities as well as the closure of risky sectors to protect Malaysians, specifically from the threat of this pandemic. As a result, there is a successful decrease in cases, which enables the Movement Control Order (MCO) to be replaced with the Conditional Movement Control Order (CMCO), and subsequently the Rehabilitation Movement Control Order (RMCO).

Nevertheless, MCO, which was introduced on 18 March 2020, has somehow introduced Malaysians to a new norm, including the usage of social media and online applications for multiple purposes and needs. The Malaysian Communications and Multimedia Commission (MCMC) reported a sharp increase in demand for broadband since the implementation of the because business activities, learning, conferences, and meetings and are conducted from home. Compliance with the MCO in force witnessed an increase of $23.5 \%$ in terms of internet traffic flow nationwide in the first week of MCO, and this further increased by $8.6 \%$ in the second week (SKMM, 2020). The influx of information and communication technology (ICT) has greatly eased the life of people in the society. Many 
works and services are accessible and manageable online swiftly. However, not all users fully leverage the progress due to the development of ICT. Some of them are found to have abused the cyberspace as a platform to commit crimes and profit from others, leading to more profound cybercrimes.

According to the Deputy Minister of Communications and Multimedia, Datuk Zahidi Zainul Abidin, there was an increase in cybercrime cases by $91.37 \%$ during $\mathrm{MCO}$ from March 18 to June 30, 2020, compared to the cases reported within the same period in 2019. He highlighted among the cybercrimes that received the highest complaints were cyberbullying, fraud, data theft, and hacktivism, especially in urban areas with high internet speed (RTM, 2020). Therefore, collective and prompt actions have been taken by the authorities, especially that involve MCMC, CyberSecurity Malaysia, and PDRM to prevent these criminal activities from spreading like wildfire, thereby protecting users of social media and online applications from being entangled with these crimes.

\section{Social Media Usage in Malaysia}

The Industrial Revolution 4.0 has brought significant changes in the digital world. The development of the digital world led by ICT is growing more sophisticated and futuristic. Also, it has a great impact on the pattern of social interaction in society. In the interactions that take place today, consumer network does indeed go beyond the geographical, religious, and racial boundaries. People can communicate fast, at minimal cost seamlessly with no boundaries. Based on the global internet usage statistics report in the second quarter of 2019, a total of 26.4 million people out of $\mathbf{3 2 . 6 8}$ million Malaysians are internet users. Internet usage is now more focused on new social media such as Facebook, Twitter, Instagram, and Whatsapp. Nevertheless, lately we are presented with such unhealthy symptoms that occur among citizens of the digital world, involving abuse in the social media. These symptoms include cyberespionage and cyberbullying, the spread of defamation and fake news, uncivilised comments and hate speech, besides inciting racist and religious sentiments.

The usage of social media and online applications in Malaysia is regulated by the Malaysian Communications and Multimedia Commission (MCMC). MCMC's role is to implement and enforce the provision of communication and multimedia laws, to regulate all matters related to communication and multimedia activities, to control and monitor communication and multimedia activities, and to take action on any complaint related to communication and multimedia. Based on the report, a total of 11,235 complaints related to the new media were recorded during January-June 2020, encompassing hacktivism, online gambling, promotion of prostitution, copyright infringement, forgery, pornography, sedition, and so on. Of the total, 11,216 or $99.83 \%$ of complaints were successfully addressed, $80.56 \%$ complaints had been referred to the officer in charge to give advice, guidance, and education to the community, $18 \%$ complaints had been referred to social media platform providers for further action based on terms and conditions, and $1.27 \%$ were found to be in breach of provisions under Section 233 of the Communications and Multimedia Act (CMA) 1998 (MCMC, 2020). In general, online fraud, cyberbullying as well as fake and seditious news were found to predominate the cyber crime cases throughout MCO, which saw an increase in complaints related to these three forms of crime.

In fact, this era of globalisation has witnessed further revolution of today's technology, especially that involves cyberspace. The growing trend of borderless communication has seen an increase in the use of ICT technologies such as computers and mobile phones. Although the existence of a world without boundary is deemed to provide a positive impact, there are 
also negative effects such as symptoms of cyberbullying. Cyberbullying is defined as the use of technology-oriented communications including cellular phones, emails, instant messaging, and social networks aimed at stirring up harassment or intimidation against individuals through online messages or expressions (Hasniza et al., 2018). What is even more worrying, these symptoms become more severe and evolving in many forms, thus spark warnings from the authorities. The MCO implementation in a way exacerbates these symptoms because people had more spare time and experienced stress while at home (Basir et al., 2020).

The exasperation of having to face the new norm throughout the threat of COVID-19 shall not be abused to disseminate fake information in such a way that triggers panic among the public. This life-threatening pandemic shall be taken seriously, rather than being treated as materials for entertainment and evoking public outrage. The public also needs to be more cautious in receiving and spreading any information, especially the truth of those statements that is highly questionable (Anuar et al., 2018). Any information related to COVID-19 can be obtained from the official portal of the Ministry of Health Malaysia (MOH). On top of that, MCMC does provide facilities to verify the information through Sebenarnya.my portal as a platform for the public to identify the status of information that is hovering on social media.

However, in the first 6 months of 2020, it was found that cases related to the spread of fake news are higher than the offences of sedition. The community's experience in dealing with the threat of the COVID-19 epidemic to the point of inducing new norms has given rise to the latest excitement on social media, especially by sharing and spreading fake news related to the Movement Control Order (MCO), Bantuan Prihatin Nasional (BPN), assistance from the Social Welfare Department (JKM), and matters relating to the COVID-19 pandemic. Access to more information that is available online has led to a dumping of data by the public on social media. The habit of spreading fake news only results in negative cognition in society thus giving rise to panic, excitement, and emotional battle which eventually leads to an unpleasant atmosphere (Basir et al., 2020).

According to the Chief Executive Officer of CyberSecurity Malaysia (CSM), Datuk Dr Amirudin Abdul Wahab, the community needs to be more sensitive and alert for the grave threat of cyberbullying since it is more vicious than physical bullying. The cyberbullying incidents can be committed by anyone without any control because this involves cyberspace. The identity of the bully is sometimes hard to identify because the internet does provide the 'anonymity' setting. Moreover, access to the content uploaded by the bully keeps repeating because the materials shall remain in the cyberspace until it is deleted by the perpetrator. This causes some victims of bullying feel stressed, in some cases this urges the victims with the desire to commit suicide (Hasniza et al., 2018).

The Institute for Youth Research Malaysia (IPPBM) in 2017 conducted a study on 1382 youths aged 15 to 30 years old in six zones, namely the Northern Zone, Eastern Zone, Central Zone, Southern Zone, Sabah, and Sarawak. This study was conducted to analyse the cyberbullying phenomenon among youths in Malaysia. It was found that the majority (62.3\%) of respondents had been the victims of cyberbullying, where $1.21 \%$ of them are facing emotional stress to the point of attempting suicide (IPPBM, 2017). According to this study, female respondents are more susceptible to the incidents of cyberbullying (58.19\%) in comparison to males (41.81\%). A study by the United Nations Children's Fund (UNICEF) and the MyHealth Malaysia portal on more than 5,000 respondents revealed that 3 out of 10 youths in Malaysia are victims of cyberbullying, in a way this affects their education and social life. (Regina Maria, 2019). 
DEVELOPMENT

Vol. 11, No. 1, 2022, E-ISSN: 2226-6348 @ 2022 HRMARS

The rapid advancement of information and communication technology in line with the Industrial Revolution 4.0 era has made everything at our fingertips. Although there are many benefits of ICT development, in another perspective the aspect of privacy and security for each cyberspace user shall be given the utmost attention (Windarsih \& Choiriyati, 2019). The sophistication of technology should not erode the human values among cyber users to the point it is used as an instrument to manipulate and encroach on the rights of their fellow human beings. In fact, the ethical use of social media and online applications can make the cyberspace a new platform that is practical to carry out activities and fulfil current needs.

\section{Research Methodology}

The study was conducted quantitatively using a survey design. A set of questionnaires was handed over to selected respondents to obtain the data required in the study. The study sample involves social media users among female youths in Melaka. Based on the Krejci and Morgan's (1970) table, the estimated sample size shall be 400 . However, upon evaluation, only 296 respondents are eligible to be chosen as the study sample. The selection of the study sample was conducted via purposive sampling technique, where the sample fulfils specific criteria and coincides with the objectives of the study. Respondent profile was obtained from the response highlighted in the questionnaire, which was distributed to all respondents via Google Form. The description process focuses on the respondents' demographic factors such as age, social media platform, duration, and purpose of surfing the internet.

To test the validity and reliability of the items in the selected questionnaires prior to the actual study, a pilot study was conducted to identify the feasibility of the usage of instrument towards the study respondents in its entirety, especially those that involve the use of terminology and sentence structure. Respondents in the pilot study were selected via simple random sampling consisting of 30 social media users, all are female youth in Melaka. Findings of the pilot study are as follows:

\begin{tabular}{|c|c|}
\hline $\begin{array}{c}\text { Cronbach's } \\
\text { Alpha }\end{array}$ & N of Items \\
\hline .753 & 24 \\
\hline
\end{tabular}

Table 1: Reliability Statistics

Based on Table 1, Cronbach's Alpha for all items was.753 with 24 items measured are acceptable. According to Sproles and Kendall (1986), Cronbach's Alpha is a measure of internal consistency, i.e. the extent to which it relates to a set of items as a group. It is deemed a measure of scale reliability of factors where the Cronbach's Alpha coefficient of 0.4 or higher is deemed acceptable. Therefore, we can conclude that Cronbach's Alpha for all variables in this study is deemed acceptable.

Once the data obtained from the questionnaire were collected and recorded in the form available in the SPSS programme, they shall be analysed and presented in the form of descriptive statistics (Zulkarnain \& Hishamuddin, 2001). According to Baba (1997), descriptive statistics are used to describe the state of the data found in the study sample. It is the process of collecting data, making conclusion, and presenting the conclusion in the form that is easy to be understood by the target group. Via the SPSS method, a researcher can estimate the mean, standard deviation, variance, and other information of a variable (Mahdzan, 1983). In addition, descriptive statistics aims to provide a systematic description of the facts and 


\section{DEVELOPMENT}

Vol. 11, No. 1, 2022, E-ISSN: 2226-6348 @ 2022 HRMARS

characteristics of a population or field of interest in a factual and accurate manner (Sidek, 2000). Analysis was performed using the Statistical Package for the Social Sciences (SPSS) for Windows version 22.0 software.

\section{Findings and Discussion}

Based on the study that has been conducted, analysis of the findings obtained is as follows:

\section{a) Respondent Demographic Analysis}

Respondent profiles were formed to look at the characteristics of the respondents in this study as well as to identify and provide information about the background of the respondents. The profile of the respondents derived from the questionnaire is as follows:

\begin{tabular}{|c|c|c|}
\hline Type & Frequency & $\begin{array}{l}\text { Percentage } \\
\text { (\%) }\end{array}$ \\
\hline \multicolumn{3}{|l|}{ Age } \\
\hline 15 to 25 years & 214 & 72.3 \\
\hline 25 to 35 years & 65 & 21.9 \\
\hline 35 to 45 years & 17 & 5.8 \\
\hline \multicolumn{3}{|c|}{ Frequently Used Social Media } \\
\hline Facebook & 14 & 4.6 \\
\hline Twitter & 41 & 13.8 \\
\hline Whatsapp & 111 & 37.4 \\
\hline Telegram & 4 & 1.4 \\
\hline Instagram & 52 & 17.4 \\
\hline Youtube & 44 & 14.7 \\
\hline Tik Tok & 21 & 7.1 \\
\hline Others & 12 & 3.6 \\
\hline \multicolumn{3}{|c|}{ Purpose of Surfing the } \\
\hline Internet Play Game & 12 & 4.1 \\
\hline Information/Learning & 91 & 30.7 \\
\hline Get Rid of Boredom & 104 & 35.1 \\
\hline Completing Assignment & 72 & 24.3 \\
\hline Others & 17 & 5.8 \\
\hline \multicolumn{3}{|l|}{ Internet Surfing Period } \\
\hline Below 1 hour & 2 & 0.5 \\
\hline 1 to 3 hours & 34 & 11.5 \\
\hline 4 to 6 hours & 111 & 37.4 \\
\hline 6 hours and above & 149 & 50.6 \\
\hline
\end{tabular}

Table 2: Demography of Respondents

Table 2 shows the number and percentage of respondents by age. According to the demographic analysis, this study involves three categories of age groups, namely 15 to 25 years, 25 to 35 years, and 35 to 45 years. Majority of respondents are in the category of 15 to 25 years, which consists of 214 people (72.3\%), followed by 65 respondents aged 25 to 35 years $(21.9 \%)$ another group of respondents aged 35 to 45 years has 17 people $(5.8 \%)$. In terms of social media being used the most, majority of respondents consisting of 111 people 
use Whatsapp (37.4\%), followed by 52 who frequently use Instagram (17.4\%), 44 prefer Youtube (14.7\%), 41 prefer Twitter (13.8\%), 21 prefer Tik Tok (7.1\%), 14 prefer Facebook (4.6\%), 12 use other applications (3.6\%), while the remaining 4 use Telegram (1.4\%). In terms of the purpose of surfing the internet, most of them consisting of 104 people want to get rid of boredom (35.1\%), followed by 91 who are seeking for information or learning $(30.7 \%), 72$ are to complete their tasks (24.3\%), 17 surf the internet for other purposes (5.8\%) while the remaining 12 use the internet to play games (4.1\%). The next demographic analysis involves duration of internet surfing, which is split into 4 categories, namely less than 1 hour, 1 to 3 hours, 4 to 6 hours, as well as 6 hours and above. Most of the respondents consisting of 149 people spend 6 hours and above (50.6\%), followed by 111 who use 4 to 6 hours (37.4\%), 34 spend 1 to 3 hours (11.5\%), while the remaining 2 only spend less than 1 hour to surf the internet $(0.5 \%)$.

\section{b) Descriptive Analysis}

Descriptive analysis provides a summary and information on the data used in this study. This analysis was conducted to look at the respondents' engagement and exposure to the incidents of cyberbullying in social media.

\begin{tabular}{|c|c|c|c|c|c|c|}
\hline \multirow[t]{2}{*}{ No } & \multirow[t]{2}{*}{ Question } & \multicolumn{5}{|c|}{ Percentage } \\
\hline & & SD & D & $\mathbf{N}$ & A & SA \\
\hline 1 & I was once humiliated on social media & 17.8 & 31.5 & 12.4 & 21.7 & 16.6 \\
\hline 2 & $\begin{array}{l}\text { I once received threats and tests on social } \\
\text { media }\end{array}$ & 21.1 & 39.2 & 8.9 & 19.3 & 11.5 \\
\hline 3 & $\begin{array}{l}\text { I used to make fun of any contact on social } \\
\text { media }\end{array}$ & 29.1 & 22.3 & 11.8 & 5.7 & 1.0 \\
\hline 4 & $\begin{array}{l}\text { I once received embarrassing and insulting } \\
\text { comments on social media }\end{array}$ & 49.0 & 11.8 & 5.1 & 21.6 & 12.5 \\
\hline 5 & $\begin{array}{l}\text { I used to spread fake news or information on } \\
\text { social media }\end{array}$ & 59.9 & 20.3 & 8.8 & 8.0 & 3.0 \\
\hline 6 & $\begin{array}{l}\text { I enjoy seeing other individuals being ridiculed } \\
\text { and bullied on social media }\end{array}$ & 82.8 & 13.9 & 2.0 & 1.4 & 0 \\
\hline 7 & $\begin{array}{l}\text { I once received sexual harassment on social } \\
\text { media }\end{array}$ & 48.0 & 14.9 & 12.2 & 14.5 & 10.5 \\
\hline 8 & My personal social media site has been hacked & 53.7 & 16.2 & 9.8 & 16.2 & 4.1 \\
\hline 9 & $\begin{array}{l}\text { I once uploaded videos and other individual } \\
\text { submissions without giving credit to the original } \\
\text { owner }\end{array}$ & 62.5 & 19.3 & 14.9 & 2.7 & 0.7 \\
\hline 10 & $\begin{array}{l}\text { My appearance on social media is often used as } \\
\text { a joke }\end{array}$ & 55.9 & 24.7 & 7.4 & 10.7 & 1.4 \\
\hline 11 & $\begin{array}{l}\text { I once edited and modified pictures of other } \\
\text { individuals for prank purposes }\end{array}$ & 71.0 & 16.6 & 8.8 & 3.4 & 0.3 \\
\hline 12 & $\begin{array}{l}\text { My videos or writings on social media are } \\
\text { shared without permission }\end{array}$ & 61.8 & 18.6 & 8.8 & 7.1 & 3.7 \\
\hline 13 & $\begin{array}{l}\text { I once hacked my friend's social media account } \\
\text { for a joke }\end{array}$ & 77.7 & 16.2 & 2.0 & 4.0 & 0 \\
\hline 14 & $\begin{array}{l}\text { I enjoy attacking the social media accounts of } \\
\text { any individual linked to a controversy }\end{array}$ & 59.1 & 23.5 & 1.0 & 4.0 & 2.3 \\
\hline 15 & $\begin{array}{l}\text { My personal photos were once modified and } \\
\text { disseminated as satire }\end{array}$ & 62.6 & 16.2 & 5.7 & 9.1 & 6.4 \\
\hline
\end{tabular}

Table 3: Descriptive Analysis 
According to Table 3, the most frequent cyberbullying harassment ever experienced by respondents is humiliation on social media (38.3\%), followed by embarrassing and insulting remarks $(34.1 \%)$, threats and insults $(30.8 \%)$, sexual harassment $(25 \%)$, personal social sites were hacked $(20.3 \%)$, personal photos were altered $15.5 \%$, being ridiculed and trolled on social media (12.1\%), as well as having their videos or writing shared without permission $(10.8 \%)$. Although the pattern of cyberbullying among respondents is still moderate on average, it shall be addressed thoughtfully as social media is supposed to be a safe platform for all users. From the perspective of the pattern of cyberbullying behaviour, it was found that the respondents do not make such behaviours a norm. On average, some respondents used to mock their acquaintance (6.7\%), attack other social media users' accounts (6.3\%), hack the accounts of their social media contacts (4.0\%), alter photos of other individuals (3.7\%), share videos or posting without credit to the original owner (3.4\%), and enjoy seeing other individuals being bullied on social media (1.4\%). Thus, it is concluded that cyberbullying behaviour is relatively low among female users of social media, instead they are more at risk of being exposed as victims to cyberbullying harassment.

\section{Conclusion}

The usage of social media is now crucial for every member of society, especially in the era of the Industrial Revolution 4.0. Yet, its unethical use leads to the abuse of social media for purposes that violate societal norms and the law. The trend of cyberbullying seems to be more prevalent nowadays and if such incidents are not curbed, this can lead to serious repercussions on society. Women are seen to be the main target of these incidents in comparison to men, which can affect their psychological wellbeing. This kind of risk could be more critical due to the pressing need for internet access during the enforcement of the Movement Control Order (MCO) period. Therefore, this study contributes to the present body of knowledge on cyberbullying in digital media in Malaysia. The main contribution of this article provides directions for the harmonious interaction in digital platform. Suggestion for future study to explore the understanding of the implications of cyberbullying behavior in Malaysia. This is valuable finding that contribute towards the harmony of a digital society in Malaysia, as well as achieving the national cybersecurity agenda. Thus, exposure to the rights as social media users as well as proper support systems shall be provided to protect them from being exposed as victims of this crime. Social media platforms should be a safe space for interaction and free from any threats, harassment, and invasion of privacy by any party. Therefore, each party must take the initiative to create a harmonious digital ecosystem by practising self-control in the usage of social media.

\section{Acknowledgement}

This paper is one of the research output made for fulfilling the TEJA Research Grant (Universiti Teknologi MARA Cawangan Melaka) requirement under the project entitled, 'Cyber Bullying Behavior in Digital Media Among Youth in Melaka According To Islamic Perspective' numbered GDT2021/1-7

\section{References}

Alim, S. (2017). Cyberbullying In The World Of Teenagers And Social Media: A Literature Review. In Information Resources Management Association, Gaming and Technology Addiction: Breakthroughs in Research and Practice, 520-552. 
Ansong, E. D., Tony, T., Dominic, D. E., Ampomah, A., \& Larkotey, W. (2013). Internet Trolling in Ghana. International Journal of Emerging Science and Engineering, 2(1), 42-43.

Astro Awani. (2019). MCMC Perlu Diberi Kuasa Padam Berita Palsu, Fitnah Serta Perkauman, https://www.astroawani.com/berita-malaysia/mcmc-perlu-diberi-kuasa-padamberita-palsu-fitnah-serta-perkauman-200518, dicapai pada 12 September 2020.

Berita Harian. (2020). COVID-19: Pesakit trauma akibat cemuhan netizen, https://www. bharian.com.my/berita/nasional/2020/04/682940/covid-19-pesakit-trauma-akibatcemuhan-netizen, dicapai pada 17 September 2020.

Berita Harian. (2018). Ancaman Buli Siber, https://www.bharian.com.my/berita/nasional/2018/01/370155/ancaman-buli-siber, dicapai pada 17 September 2020.

Bernama. (2019). Buli Siber Perlu Ditangani Segera. https://www.bernama.com/bm/news.php?id=1791049, dicapai pada 17 September 2020.

Griffiths, M. D. (2014). Adolescent Trolling In Online Environment: A Brief Overview. Education and Health Journal, 32(3), 85-87.

Harian Metro (2020). Mangsa Buli Siber Boleh Bertukar Jadi Pembuli. https://www.hmetro.com.my/mutakhir/2020/05/575040/mangsa-buli-siber-bolehbertukar-jadi-pembuli, dicapai pada 17 September 2020.

IPPBM. (2017). Buli Siber dalam Kalangan Remaja di Malaysia. https://www.ippbm.gov.my/jdownloads/Infografik\%20penyelidikan/Buli\%20Siber\%20 Dalam\%20Kalangan\%20Belia\%20Malaysia.pdf

Morissey, L. (2010). Trolling Is A Art: Towards A Schematic Classification Of Intention In Internet Trolling. Griffith Working Papers in Pragmatics and Intercultural Communication, 3(2), 75-82.

O’Neill, M., Calder, A., \& Allen, B. (2014). Tall Poppies: Bullying Behaviors Faced By Australian High-Performance School-Age Athletes. Journal of School Violence, 13(2), 210--227.

Cohen-Almagor, R. (2018), Social responsibility on the Internet: Addressing the challenge of cyberbullying, Aggression and Violent Behavior, 39, 42-52.

Ruiz, R. M. N. M. (2019). Curbing Cyberbullying among Students: A Comparative Analysis of Existing Law among Selected Asean Countries. PEOPLE: International Journal of Social Science, 4(3), 1285-1305.

Zakaria, Z., \& Hishamuddin, M. S. (2001), Analisis Data Menggunakan SPSS Windows, Skudai: Penerbit Universiti Teknologi Malaysia. 